\title{
Implementation Of Law Protection Of The Equal Rights For Disability People In Aerial Transportation
}

\author{
Willy Putra
}

Faculty of Law, Tarumanagara University, Jakarta

\begin{abstract}
Rights in human rights have a position or prime and first degree in community life Article 281 Paragraph 2 of the 1945 Constitution provides that everyone is free from discriminatory treatment. However, discriminatory treatment still occurs misses in the case of Dwi Aryani Vs Etihad Airways which is derived by the airline on the grounds that he is a person with disabilities who are in wheelchairs and no counselors. How the implementation of legal protection by airlines on equal rights for groups of People with disabilities in aviation transport The author examines this issue using legal research methods for academic purposes. The research data shows that the airport does not yet have complete facilities for groups of People with disabilities, the absence of technical regulations / implementers that further regulate the Law No. 8 of 2016, lack of socialization and education to the public, airport service providers, airlines, and field officers. This is why the protection of groups with disabilities is less effective. Governments should issue technical / implementing regulations related to the Disability Law, and conduct socialization and education to the public, airport facility providers, airlines and field workers.
\end{abstract}

Keywords: Groups Of People With Disabilities, Discrimination, Human Rights

\section{Research Background}

Rights in human rights have a position or first and foremost degree in social life because the existence of basic human rights has been possessed, carried, and inherent in the human person since his birth. Instantly also appeared the obligation of other humans to respect it (A. Masyhur Effendi, 2005).

In Indonesia, related to the principle of non-discrimination itself can be seen from the 1945 Constitution precisely in Chapter XA on human rights Article 28A-28J, which says "Every person is free from discriminatory treatment on any basis and has the right to get protection from the treatment discriminatory "(Article 28I Paragraph 2) which is clear from this article that Indonesia has accommodated the principle of nondiscrimination and Indonesia has also stated that protection, promotion, enforcement and fulfillment of human rights is the responsibility of the state, especially the government (Article 28I Paragraph 4).

Corresponding author: Willy Putra

willyputra2001@gmail.com

Published online at http://IJDS.ub.ac.id/

Copyright (C) 2019PSLD UB Publishing. All Rights Reserved
In addition to the rules above related to discrimination treatment, there are other rules that have also governed the prohibition of discrimination treatment, namely Law Number 39 of 1999 concerning Human Rights which states that: "Everyone has the right to the protection of human rights and basic human freedoms, without discrimination" and As for other provisions, namely Law Number 8 of 2016 concerning People with Disabilities (Article 2), which states: "The implementation and fulfillment of the rights of People with disabilities is based on: respect for dignity, individual autonomy, without discrimination, full participation, human diversity and humanity, equality of opportunity, equality, accessibility, capacity that continues to develop and the identity of children, inclusive, and special treatment for more protection. "From the aforementioned provisions, it is clear from the regulatory point of view that it is explicitly stated that discrimination is an act which is prohibited by the state."

Then the protection by the state of the rights that must be granted to People with disabilities in proper public services has been 
specifically regulated in Law Number 25 of 2009 concerning Public Services Article 29 Paragraph (1) states that: "The Operator is obliged to provide services with treatment specifically to certain community members in accordance with the laws and regulations ". Furthermore Law No. 8 of 2016 concerning People with Disabilities states that: "The Government and Regional Governments must provide Public Services that are easily accessible by People with disabilities in accordance with the provisions of the regulations From both provisions above it is clear that People with disabilities have the right and are entitled to special treatment of public services.

For example in the case of aviation transportation, in accordance with Law Number 1 of 2009 concerning Aviation the contents of which are: "That People with disabilities, elderly people, children under the age of 12 (twelve) years, and / or sick people are entitled to receive services in the form of special treatment and facilities from the commercial air transport business entity. Then there is Ministerial Regulation Number 61 Year 2015 Chapter III concerning the division of tasks and responsibilities in letter D number 10 related to airport operators must provide, maintain, and optimize facilities and services for passengers with reduced mobility or People with disabilities. After that there is Minister Regulation No. 98 of 2017 concerning Provision of Accessibility in Public Transportation Services for Users with Special Needs which is the latest ministerial regulation. It is clear from the various provisions mentioned above that facilities and services must be provided for disabled passengers, but regarding the practice of its application in the field there are still many questions that are questioned.

For case Study, Dwi Aryani Vs Etihad Airways, Starting when Dwi Aryani received an invitation from the International Disability Alliance (IDA) to attend a training on "Deepening Implementation and Monitoring of the Convention on the Rights of People with Disabilities" in Geneva, Switzerland, when they were about to leave to attend the meeting, Dwi Aryani was asked to check in the etihad counter, and he was told that he needed a special wheelchair to get into the aircraft cabin. This is usually done before flying, and when boarding is also escorted by officers into the plane.

The problem arose after 20 minutes Dwi Aryani was on the plane, the crew leader came over and chided Dwi Aryani with several questions, which undermined the disability group. The questions asked were, can you evacuate yourself if the plane crashes, Dwi Aryani answered, I need someone to help me evacuate, then came the airport operation officer, he again asked if Dwi Aryani could walk, he answered that he could walk with a handle, then he said according to the cabin crew, he had to get off the plane because there was no companion (Change.org, 2018).

From this case we can see that the government has neglected its responsibilities to People with disabilities according to Law Number 39 of 1999 concerning Human Rights in Article 71 which states, "The government is obliged and responsible to respect, protect, uphold and advance the human rights stipulated in this law, other laws and regulations, and international law concerning human rights accepted by the Republic of Indonesia".

Therefore, the state which should have the main obligation to protect and advance human rights, often becomes the main actor in human rights violations ( $\mathrm{Al}$ araf and $\mathrm{M}$. Ali Syafaat, 2005). Even though it was not directly caused, the government has neglected to guarantee human rights, thus causing violations of human rights in terms of discrimination against People with disabilities.

Based on the research background above, the researchers want to examine how the implementation of legal protection by airlines against equal rights for groups of People with disabilities in Aerial transportation.

\section{Methods}

The type of research used in this study is Legal research for academic purposes is used for compiling academic work (Peter Mahmud Marzuki, 2016) to find the rule of law, legal principles, as well as legal doctrines to answer legal issues that related to Implementation Of Law Protection Of The

Cite this as: 
Equal Rights For Disability People In Aerial Transportation.

Types and Sources of Legal Materials are Primary Legal Material, which is authoritative, Secondary Legal Material, that is legal material which is not binding but provides an explanation of the legal material primer and helps the process of understanding and analyzing the material primary law. Non-Legal Materials, namely supporting materials outside the material primary or secondary law as supplementary material is not the main one and provide additional instructions for the legal research.

Research studied in this research is prescriptive research, which is intended to provide arguments for the results of research have been done.

Technique collection of legal materials that support and relate to The presentation of this research is the study of documents / library materials research). Document study is a legal material collection tool done through written legal material using content analysis.

In this case the material processing is done by doing selection of legal material, then carry out classification according to classification of legal materials and compile the results of these studies collapsed and systematically into classes of symptoms the same or considered the same so that makes it easier for writers in do the analysis.

This study uses the study of legal materials in a logical way deductive. Deductive logic or processing of legal materials in a way deductive, which explains something that is general then turn it into more specific conclusions.

The approach method used by the writer in the proposal writing this thesis is a statute approach and conceptual approach. The law approach is carried out by examining all laws and regulations related to legal issues handled. Whereas the conceptual approach departs from views and doctrines that develop in legal science, by studying the views and doctrines in science law, researchers will find ideas that give birth to understanding of law, legal concepts, and legal principles relevant to the issue at hand.

\section{Result and Discussion}

\subsection{Theory}

\section{a. Legal Protection}

Philipus M. Hadjon believes that legal protection is the protection of dignity, as well as recognition of human rights owned by legal subjects based on the legal provisions of arbitrariness (Philipus M. Hadjon, 1987).

Philipus M. Hadjon divides legal protection into 2 types. The first one is Preventive Legal Protection, based on the research of a team from the Council of Europe on The Protection of the Individuals in Relations in Acts of Administrative Authorities that discusses the right to be heard as a means of preventive legal protection. The research formulated two important meanings from the right to be heard, Individuals affected by governmental acts can express their rights and interests and Such a way of supporting a good administration (good administration) and can be added to the atmosphere of mutual trust between those who rule and those governed. The second one is Repressive legal protection, There are two sets of courts for repressive legal protection in countries that adopt a civil law system, namely a general court (in Indonesia called the District Court) and an administrative court (in Indonesia called the State Administrative Court). Whereas in countries that adhere to the common law system only knows one set of court namely ordinary court.

\section{b. Legal Utility}

Utilization is one of the most important goals of the law, for adherents of utilitarianism, they cleanly say that the sole purpose of law is to achieve benefits. Good law is a law that brings benefits to humans (Fence M. Wantu, 2007).

So this comprehension assesses whether it is good or not, moral or not, in terms of usefulness or benefits that it brings (Burhanuddin Salam, 2000).

Utilization here is defined as happiness, which does not matter the good or unfairness of a law, but rather depends on the discussion of whether the law can provide happiness to as many people as possible or not (Muhamad Erwin, 2015).

Jeremy Bentham, with his book "Introduction to the Principles of Morals

Cite this as:

Willy Putra, Implementation Of Law Protection Of The Equal Rights For Disability People In Aerial Transportation. Indonesian Journal of Disability Studies (IJDS).2019: Vol. 6(2): PP 259-268 
amd Legislation" formulates the principle of utilitarianism as "the greatest possible happiness of the greatest number". According to Bentham, this principle must underlie political life and legislation.

The purpose of law is to achieve and guarantee happiness for the people (the greatest happiness of the greatest number). According to utilitarianism, good and bad criteria that must exist in the law must originate from happiness itself. The principle of expediency is intended to test and evaluate all policies and regulations set by the government. The function of the state according to utilitarianism must realize happiness as much as possible for society and this is a function of the tool not a function of purpose (Khazanah, 2015).

\section{c. Human Rights}

Rights must be respected, upheld and protected, which does so, the state, the law, the government and everyone (Salim HS dan Erlies Septiana Nurbani, 2016). The source of that right is human moral thought. The use of human rights is to maintain human dignity. From that explanation, it can be seen the nature of human rights itself, namely Human rights do not need to be given, bought, or inherited, human rights are part of humans automatically, The right of human freedom for all people regardless of gender, race, religion, ethnicity, political views or social and national origins, and Human rights cannot be violated. No one can limit or violate the rights of others. A person still has human rights even though the state makes laws that do not protect or violate these rights (Fulthoni, 2009).

\section{d. Legal Culture}

According to Achmad Ali, as quoted to Friedman, the legal system consists of legal structure, legal substance, and legal culture (Rocky Marbun, 2014). Actually Friedman in his book explain that there are 4 components of the legal system, the fourth components is impact but which will be described in this study only 3 components.
Friedman in his book explain about legal structure as "To begin with, the legal sytem has the structure of a legal system consist of elements of this kind: the number and size of courts; their jurisdiction Structure also means how the legislature is organized what procedures the police department follow, and so on. Structure, in way, is a kind of crosss section of the legal system is a kind of still photograph, with freezes the action" (Lawrence M. Friedman, 1930).

Then, legal substance as "Another aspect of the legal system is its substance. By this meant the actual rules, norm, and behavioral patterns of people inside the system. These are working patterns of the living law. Substance also means the product that people within the legal system manufacture, the decision they turn out the new rules they contrive".

The last one is legal culture, that explained as "The third component of legal system, of legal culture. By this we mean people's attitudes toward law and legal system their belief, in other word, is the climinate of social thought and social force wicch determines how law is used, avoided, or abused".

From the explanation above the way to conclude about the component above is, The structure is likened to a machine, Substance is what is done and produced by the machine, and Legal culture is anything or anyone who decides to turn on and turn off the machine, and decides how the machine is used (Achmad Ali, 2002).

In this matter will be discussed further about the legal culture, legal culture is an important thing to discuss when talking about the law, because it contains the potential to be used as a source of information to explain the legal system. Sometimes it is difficult to explain why the legal system cannot be carried out as it should or undergo an implementation that is different from the original pattern, if not involving about legal culture (Satjipto Rahardjo, 2014). Without legal culture, the legal system is helpless, like a dead fish lying in a basket and unlike a fish that swimming 
in the sea (Achmad Ali, 2002). The legal culture of society can also be given the same limits as social legal awareness (Dardji Darmodihardjo dan Shidarta, 1996).

\section{e. Discrimination}

Types of Discrimination according to Fulthoni explain Types of discrimination that usually happens in the society such as (Fulthoni, 2009):

1) Discrimination, based on ethnicity, race and religion / creed;

2) Discrimination based on sex and gender (social roles due to gender);

3) Discrimination against people with disabilities;

4) Discrimination against people with HIV / AIDS;

5) Discrimination on Social Level.

Refer to Pettigrew, there were two types of discrimination (Liliweri Alo, 2005):

1) Direct Discrimination, The act of restricting a particular area, such as settlements, types of work, public facilities and the like and also occurs when decision makers are directed by prejudices against certain groups;

2) Indirect Discrimination, Indirect discrimination is carried out through the creation of policies that prevent certain racial / ethnic groups from engaging freely with other racial / ethnic groups where the rules and procedures they undergo carry out invisible discrimination bias and result in systematic harm to certain communities or groups of people;

Causes of Discrimination, Yahya said that there were some causes of discrimination such (Kresentia Renata, 2001):

1) Psychological defense mechanism (projection), someone transfers to others the characteristics that are not liked about themselves to others;

2) Disappointment, half of people who are disappointed will put their disappointment to the scapegoat;

3) Experiencing insecurity and low self-esteem, those who feel threatened and inferior to calm down then they try to humiliate other people or groups;

4) History, caused by factors from the past;

5) Competition and exploitation, society now is more materialistic and lives in competition. Individuals or groups compete among themselves for wealth, luxury and power;

6) The style of socialization, discrimination is also a phenomenon that is learned and passed down from one generation to another through the process of socialization. Furthermore, a stereotypical view of the role of a nation and others in society is formed, namely regarding behavior, ways of life and so on. Through this stereotypical view, children learn to judge someone or an idea. Prejudice attitudes are also learned through the same process.

\subsection{Implementation of Legal Protection by Airlines Against Equal Rights for People with Disabilities in Aviation Transport}

The Basic Protection for discriminations act, can be found at the 1945 Constitution precisely in Chapter XA on human rights Article 28A-28J, especially on Article 28I Paragraph 2: "Every person is free from discriminatory treatment on any basis and has the right to get protection from the treatment discriminatory.

In fact, discriminatory treatment still often occurs, especially for groups of people with disabilities they are always considered / labeled that they are different from others, whereas groups of people with disabilities are also citizens who must be protected by the government without regard to the physical limitations possessed by them. 
The government as the main holder of responsibility in carrying out efforts to protect, promote, enforce and fulfillment for human rights still cannot meet the provisions of Article 28I Paragraph 2 of the 1945 Constitution.

For example, in fulfilling the rights of groups of people with disabilities especially the right to have proper accessibility, the government still tends to not provide adequate facilities, for example at the airport, there are still no special facilities for persons with disabilities who are blind, how do they know airline flight schedules, if there is no special access provided, how can they get their rights to enjoy this accessibility. Then in terms of being free from discrimination, for example, Dwi Aryani himself was demoted by etihad airways only because he was not accompanied by a companion, and was asked questions that pertained to the physical conditions owned by Dwi Aryani such as whether to walk, whether he could evacuate himself, this is clearly a discriminatory act so that the government carries out its obligations and responsibilities.

Indeed, if it is said that the government does not provide protection of course it is wrong, because the government so far has provided protection in a repressive form, but this has not been effective given that discriminatory treatment is actually an issue that has an impact not only on conditions that are momentary, but discriminatory attitudes especially those with disabilities who discriminate against them based on their physical condition will certainly cause a sense of trauma / depression because remembering that the condition they experienced could be congenital, which indeed happened not because of their will or desire. So that groups of people with disabilities cannot vote, this will definitely hurt the group of people with disabilities mentally as well. So that the government should provide protection with preventive forms, which have not yet occurred discriminatory treatment, because given that everyone has different sensitivity, a sense of forgetting that is different so that it will be better if the government can accommodate and provide preventive protection.
There are actually various types of discrimination whether it is based on ethnicity, race, religion, customs, or one's physical condition. The most common case for groups of people with disabilities is of course based on their physical condition, then the discrimination tends to be direct and the form of discrimination is done verbally expressed through insults or words that tend to be caused by the style of socialization, which is passed down from one generation to another generation in this case it is from parents to their children, who provide a stereotypical view that people with disabilities are different and must be avoided should not be accompanied / associate with groups of people with disabilities so that the style of socialization that affects a person to judge others based on their physical condition.

Determining someone to be discriminated against is difficult to give a measure, considering that someone can feel that he has been discriminated against is very influenced by the subjective element where each person's subjective element is different, there may be people who are more indifferent or indifferent but there are people who are very sensitive to discriminatory treatment. For example, when someone comes to a party that requires wearing white clothes, he is not allowed to enter because he does not wear white clothes, then he changes clothes using white clothes, and he can enter. The story will be different if the party requires that the person who can enter is someone who is white, of course this is discrimination based on skin color, however this way is not not his desire but he got himself from birth.

From this example, discrimination occurs if the refusal occurs due to a condition that cannot be changed or innate since birth, different rejection will be given because for example the example of durian that was brought onto the plane, because it can interfere with other parties using services same flight.

Non-discrimination is a human right that is owned by humans that does not need to be given, bought, or inherited, applies to all people regardless of sex, race, religion, ethnicity, political views or social and national origins, as well as human rights 
cannot be broken, nothing can limit or obstruct.

Human Rights highly upholds the Principle of Equality, which requires equality of equal treatment, where in different situations they are treated differently. What often becomes a problem in the principle of equality is when someone comes from a different position but is treated the same. If the same treatment continues to be applied, then of course differences will continue to exist, even though the human rights standard itself has been raised. Therefore affirmative action is a step that must be taken, affirmative action allows the state to treat more specifically to certain groups that are not represented, in the case that affirmative action can only be used in a certain measure until equality is achieved. But when equality is achieved the affirmative action must be stopped.

Actually the state has 3 obligations, the obligation to respect requires the state not to do anything or limit anything that violates the integrity of individuals or groups or violations of their freedom, in the case of groups of people with disabilities, actions such as restrictions on getting health insurance from the government, the obligation to protect requires the government to take action to protect citizens from violations of rights that occur, an example for groups of people with disabilities is when the state fails to force companies to continue employing employees who have work accidents so that they become disabled, and the obligation to fulfill more leads to guarantees from the state that guarantees the rights of groups of people with disabilities, for example when the state fails to provide guarantees / services for the basic health care system to groups of people with disabilities, the state will be said to have failed fulfill its obligations.

But from the discriminatory actions that occurred against Dwi Aryani committed by Etihad Airways, it is not entirely the point of error in the hands of the government, the legal culture of the community certainly influences how discriminatory treatment can occur, for example when a person with a disability uses facilities at the airport, then it turns out that the community others as users also stay away from these groups of people, because they see that they are different or when airline or airport officials provide assistance in services, because they have never done handling or assistance to groups of people with disabilities so officers also experience confusion about how to provide services, available in fact it is wrong to provide services so that groups of people with disabilities will again feel inferior because they inconvenience others caused by their disabilities. So that in this case it is not the government that is the focal point for the occurrence of errors / discrimination against groups of people with disabilities but the role of the community, service providers so that this becomes difficult to overcome, because too many parties are involved in fulfilling the rights for groups people with disabilities.

Of course, the protection provided to groups of people with disabilities based on reality in the field is still very minimal and not yet effective, this can be seen from the repeated repetition of discrimination cases both before the issuance of the Disability Act Number 8 of 2016, even though the government can actually be said to have there is an intention to prevent discrimination against disability groups for a long time, but this has not yet been realized despite various regulations.

Again, the protection that runs is only repressive, it is very difficult to fulfill preventive protection, even though the act of discrimination is included in the violation of human rights because ham itself highly respects the principle of non-discrimination, indeed this cannot blame the government completely but if we look at the actual government Indirectly is one of the people who took part in the occurrence of discrimination, the government allowed omission so that discrimination occurred, bearing in mind that it had been contained in the 1945 Constitution Article 28I Paragraph 4, and Law Number 39 of 1999 concerning Human Rights in Article 71 whose stated "The government is obliged to and is responsible for respecting, protecting, upholding and advancing human rights that are regulated in this law, other statutory regulations, and international law concerning human rights accepted by the Republic of Indonesia". 
It is clearly said that the government is obliged and responsible to respect, protect, uphold and advance human rights, but in reality it is still limited to writings that have not been carried out in accordance with the words contained in the Act.

If the law should be beneficial, of course it cannot be said to be beneficial protection provided by the government, so again the legal objective has not been achieved if it is focused on the benefit of the law, indeed this is influenced by the existing legal culture in the community, the low awareness of the community so as to create a legal culture who do not follow positive thinking, there are still continuing to discriminate, because of the lack of education, and socialization from the government itself.

Witnessing this, there is a great hope that every group of people with disabilities has, so that every policy determined by the government can be implemented optimally by every element of the community, because the long-term benefits and happiness of persons with disabilities can only be obtained and fulfilled through policies that pay attention to the quality of service / treatment from the community to groups of people with disabilities. Which involves all components, especially in the case of aviation such as the government through relevant ministries, airport service providers, airline service providers, officers present in the field, other consumers / communities who are all present and participate in understanding that groups of people with disabilities are not discriminated against, rather to be shunned but should be given special protection because indeed they need special treatment in order to achieve equality with the community.

Through this method it is expected that the treatment of discrimination against groups of people with disabilities can be significantly reduced because in the end they have realized that disability is not a disease, this can simultaneously fulfill preventive protection considering that although the responsibility and burden is in the hands of the state / government of course the community remains participate, so that its role is needed to achieve that protection itself.

Based on the researcher perspective on the protection of discrimination against groups of people with disabilities, that the government should carry out special socialization and educating the community on how to deal with groups of people with disabilities, not shunned but understood and can also help to realize the implementing regulations of Law Number 8 Year 2018 concerning Persons with Disabilities so that there is a specific reference on how to treat groups of people with disabilities plus the provision of education and outreach from the government and the fulfillment of facilities for persons with disabilities of course the great hope of the author that full legal protection can ultimately be fulfilled.

\section{CONCLUSIONS}

The legal protection provided to groups of people with disabilities provided by the government already exists, but it has not been effective because it is still limited to repressive protection. Indeed this is a difficult thing considering that there are various parties involved in the occurrence of a discrimination against groups of people with disabilities especially airlines. Starting from the airport service provider, airline provider, officers in the field, the community / other consumers can all be someone who discriminates against groups of people with disabilities.

Indeed, the government which holds the responsibility for guaranteeing, fulfilling and upholding human rights in this case the treatment of discrimination, but we must look at other factors that cause this discrimination, which becomes another factor due to the unavailability of special facilities in providing services to groups of people with disabilities by the airport, then the airport also does not have complete facilities for groups of people with disabilities, it is already available but not yet complete, then there are airlines that also do not provide education to field officers that disability is not a disease so it cannot be compared to someone who suffer from heart disease, and again the society itself either directly or does not discriminate against groups of people with disabilities.

This is due to the lack of legal awareness possessed by all elements of society including the service providers themselves, because the culture created already has a bad stigma against groups of

Cite this as: 
people with disabilities, this causes discrimination against groups of people with disabilities.

The government has issued various regulations relating to persons with disabilities in terms of aviation, but discrimination continues to occur, Dwi Aryani is an Indonesian representative who will be a participant in the deepening of understanding about disability issues in Geneva, Switzerland but cannot depart because of discrimination against him until he must be disembarked from the plane and not fly to attend the event. Not only the compensation sanctions needed by Dwi Aryani, the most important thing is to have the same opportunity to be present at a similar event because it is his main purpose for flying.

There are already many rules that have been issued, but there are still no rules that provide solutions or how to recover in the event of discrimination when what is needed is a solution to the discrimination, how to recover from trauma, how to restore opportunities that have been lost. can be overcome by the government. This can actually be overcome if the government disseminates and educates the public, airport service providers, airline services, and field officers, because they realize that people with disabilities are important because they are the same as other communities, not to be ostracized but rather must be protected and must issue technical / implementing regulations so as to be able to clearly divide what must be done to deal with diverse needs, not just relying on basic laws which only regulate the government obligations and rights obtained by persons with disabilities.

So the conclusion of the discussion and analysis of the problem is that the legal protection provided by the government to groups of people with disabilities based on the Dwi Aryani case is not yet effective and not enough because it is still repressive in nature and does not fulfill preventive measures, even though many discrimination rules still occur. Indeed the responsibility lies with the government but the legal culture of the community also creates the occurrence of discrimination against groups of people with disabilities themselves, the limited facilities available, the absence of special facilities, the lack of education and socialization are also factors that cause the existing protection to be ineffective. Because the government forgets that as the main obligation holder in advancing human rights tends to be the main actor in human rights violations themselves because they have been negligent in overseeing and fulfilling the protection of persons with disabilities in flight.

\section{References}

Ali, Achmad (2002). Keterpurukan Hukum di Indonesia. Jakarta: Ghalia Indonesia.

Alo, Liliweri (2005). Prasangka dan Konflik: Komunikasi Lintas Budaya Masyarakat Multikultur. Yogyakarta: PT. LKIS Pelangi Aksara.

Darmodiharjo, Darji. Dan Shidarta (1996). Penjabaran Nilai-Nilai Pancasila Dalam Sistem Hukum Indonesia. Jakarta: PT. RajaGrafindo Persada.

Effendi, A. Masyhur (2005). Perkembangan Dimensi Hak Asasi Manusia \& Proses Dinamika Penyusunan Hukum Hak Asasi Manusia. Bogor: Ghalia Utama.

Erwin, Muhamad (2015). Filsafat Hukum Refleksi Kritis Terhadap Hukum dan Hukum Indonesia (Dalam Dimensi Ide dan Aplikasi). Cetakan ke-4. Edisi Revisi. Jakarta: PT. RajaGrafindo Persada.

Friedman, Lawrence M (1930). American Law. New York: W.W. Norton \& Company.

Fulthoni (2009). Memahami Diskriminasi: Buku Saku Untuk Kebebasan Beragama. Jakarta: Indonesia Legal Resource Center.

Hadjon, Philipus M (1987). Perlindungan Hukum Bagi Rakyat Indonesia. Surabaya: PT. Bina Ilmu.

HS, Salim. Dan Erlies Septiana Nurbani (2016). Penerapan Teori Hukum Pada

Cite this as: 
Penelitian Tesis dan Disertasi. Buku Kesatu. Jakarta: PT. RajaGrafindo Persada.

Khazanah (2015). "Jeremy Bentham". Padjadjaran Jurnal Ilmu Hukum. Volume 2 Nomor 2 Tahun 2015.

Law Number 8 of 2016 about People with Disabilities

Law Number 25 of 2009 about Public Services

Law Number 1 of 2009 about Aviation

Law Number 39 of 1999 about Human Rights

Marbun, Rocky (2014). "Grand Design Politik Hukum Pidana dan Sistem Hukum Pidana Indonesia Berdasarkan Pancasila dan Undang-Undang Dasar Negara Republik Indonesia”. Padjadjaran Jurnal Ilmu Hukum. Volume 1 Nomor 3.
Marzuki, Peter Mahmud (2016). Penelitian Hukum. Cetakan ke-9. Jakarta: Kencana.

Rahardjo, Satjipto (2014). Ilmu Hukum. Cetakan ke-8. Bandung: PT. Citra Aditya Bakti.

Renata, Kresnatia (2011). Analisis Diskriminasi Terhadap Kaum Burakumin dalam Novel Misaki dan Novel Hakai. Tesis. Jakarta: Universitas Bina Nusantara.

Salam, Burhanuddin (2000). Etika Individual (Pola Dasar Filsafat Moral). Jakarta: PT. Rineka Cipta.

The 1945 Constitutions

Wantu, Fence M (2007). "Antinomi Dalam Penegakan Hukum oleh Hakim". Mimbar Hukum. Volume 19 Nomor 3. 